\title{
Police Chiefs/Sheriffs' Views on Varying Forensic Response
}

\section{Pazarena $\mathrm{L}^{\star}$}

\author{
Graduate Student, National University, Florida, United States
}

${ }^{*}$ Corresponding author: Pazarena L, Graduate Student, National University, Florida, United States, E-mail: crim_fs@yahoo.com

Citation: Pazarena L (2016) Police Chiefs/Sheriffs' Views on Varying Forensic Response. J Forensic Sci Criminol 4(1): 106. doi: 10.15744/2348-9804.4.106

Received Date: December 24, 2015 Accepted Date: February 25, 2016 Published Date: February 26, 2016

\begin{abstract}
Police Chiefs/Sheriffs' Views on Varying Forensic Response: An investigation into Florida agencies methodologies of Forensic Response and evidence collection.

Crime scene processing and forensic evidence has catapulted into modern day law enforcement. The value of fingerprint and DNA evidence is becoming incrementally more important in prosecutions. Law enforcement agencies across the nation have developed Crime Scene Units to keep up with the collection, preservation, and presentation of this valuable evidence. The basis for the agencies implementation of their units is solely on the agencies law enforcement executive (i.e. Sheriff, Chief). They decide how they wish to create and implement their units within their agency. The majority of agencies look for cost saving ways to build these units. There are no established national standards that have been put into place for crime scene processing or the creation of a Crime Scene Unit. This has led agencies to create their units based on their own experience and expertise. Some agencies utilize only sworn law enforcement, some use only civilians and many agencies have created a conglomerate between the two, utilizing their resources to the best of their abilities. This study surveyed Police Chiefs/Sheriffs to gather their opinions on the creation of their Crime Scene Units. According to the research in this study, agency officials feel that civilian Crime Scene Investigators will provide them with more identifications from forensic evidence. They also feel that by utilizing civilian Crime Scene Investigators they will achieve more prosecutions based on the forensic evidence collected. This research also indicates that there is no cost difference for an agency to employ a civilian versus a sworn law enforcement member. Understanding the positive results that may be received from correctly staffing a Crime Scene Unit and the costs that will be incurred, agencies may build units to help facilitate better laboratory results and ultimately higher closure and prosecution rates on criminal cases.
\end{abstract}

Keywords: Crime Scene Investigators; Forensic evidence; Sheriff; Police Chiefs

\section{Introduction}

\section{Background of the Study}

The simple definition of "forensic science" as we know of this term today is the use of scientific knowledge to assist in criminal investigations and legal proceedings. The science that is utilized depends on the evidence being collected. For example, if we are collecting fingerprints, deoxyribonucleic acid (DNA), or firearms, the science being implemented will differ substantially, as will the individuals that process, collect, and testify to this evidence. This study focuses on the crime scene evidence directly. The items that need to be discovered, collected, packaged, and submitted properly to lead to the identification of a person, whether that is the criminal or the victim. Specifically the focus is on fingerprint and DNA collection. The use of these disciplines in solving crimes has been in existence for centuries.

The first use of friction ridge skin to positively identify someone was done in China as early as 300 B.C, in Japan around A.D. 702, and in the United States in 1902 (Justice N. I., The Fingerprint Sourcebook). The discovery that all humans have unique fingerprints is credited to J.C.A Mayer, a German doctor, circa 1788 (Justice N. I., The Fingerprint Sourcebook). The uniqueness of fingerprints is a vital part of the identification process. Another crucial element is the permanence of fingerprints. The discovery of fingerprint permanence is credited most frequently to Sir William James Herschel, however Hermann Welcker, a German anthropologist also contributed to this profound discovery (Justice N. I., The Fingerprint Sourcebook). The uniqueness and permanence of fingerprints are the fundamental basis of individualization using this type of evidence. Henry Faulds is credited as being the first person to publish information about the value of friction ridge skin recovered as evidence in reference to identification. He wrote an article for the journal Nature in which he suggested that friction ridge detail that is left at a crime scene may be utilized to identify the person 
who left the impressions. He gave examples such as a greasy print on a glass and sooty prints on a wall (Justice N. I., The Fingerprint Sourcebook). The knowledge that unique, permanent, identifying features may be left by the perpetrators on crime scenes became vastly important to criminal investigators, especially after the Rojas homicide case. This homicide occurred in 1892 in Argentina. In this case a bloody thumbprint was recovered and identified as Francisca Rojas and led to a confession in this brutal crime (Justice N. I., The Fingerprint Sourcebook). This led to the realization that this crucial fingerprint evidence must be properly identified and collected from crime scenes.

Deoxyribonucleic acid (DNA) was first identified in the late 1860s by Swiss chemist Freidrich Miescher. In the years to follow many other notable scientists developed upon the discovery of DNA. In 1953 Francis Crick and James Watson discovered that DNA is a double helix molecule [1]. Although DNA does not have the extensive history in the law enforcement realm that fingerprints do, this evidence is becoming more and more relevant and crucial in crime scene investigations and individual identification. The increasing trend of DNA in the criminal justice system is clear, the first time DNA was utilized in court was in 1987 and by 2001 over $68 \%$ of prosecutors stated they used DNA in a felony case [2]. As the obvious demand by the criminal justice system for this type of evidence increases so do law enforcement's attempts to deliver this evidence. The type of DNA evidence that is understood to now be available to law enforcement on a crime scene has drastically changed since the 1980s. As technologies continue to change and enhance the abilities of laboratories to process DNA and identify individuals from the most minuscule amounts of evidence increases. This has led to the revelation of touch DNA collection. Now, not only does law enforcement look for the "obvious" DNA samples (blood, semen, saliva, etc.) they also look for and collect the unseen (skin cells from objects someone has touched or handled). In order for this high demand evidence to be admissible in court, law enforcement is realizing that this evidence must be properly collected and preserved.

The importance of fingerprints and DNA in the identification of an individual from a crime scene has been demonstrated for centuries. The challenges facing today's forensic and law enforcement community involve the proper identification, collection, preservation, and processing of this vital evidence. The agencies responsible for this crucial evidence collection task must also consider the financial implications of the procedures for gathering this evidence. Over the years the methodologies of collecting this evidence have varied. The methods also vary from state to state and agency to agency. There is no single standard across the United States that establishes who will collect and preserve this evidence. This has led to numerous variations depending on the higher echelons' decisions. Police Chiefs/Sheriffs make their decision as to the creation of their Crime Scene Unit and forensic processing based on their own experience, judgment, and financial capability at their agency. There are some trends in which sworn law enforcement personnel who first respond to a scene are tasked with the responsibility of processing scenes forensically. Other agencies send their sworn members through specific training and put them in a specialized "crime scene unit" where forensic processing is all they do. Many agencies have turned toward the civilian sector for this highly trained and qualified profession. The question then is, which way is better? Which of these options is going to be better for the agency, better for the laboratories, better for the courts, and ultimately better for society? The focus of this study is to answer many questions that have yet to truly be studied in this field. Minimal work has been done looking into the value of the evidence collected by personnel at different levels of training. This study intends to evaluate Police Chiefs/Sheriffs' perceptions on best practices. What is the best option, both economically and practically? Should a sworn member whose main job function is to answer citizens' calls for service also be to take on the daunting task of forensic processing? Should sworn members be utilized for this function at all whether trained and in a specialized unit or not? Should highly trained, experienced civilians be used instead of law enforcement? Which of these methods provides the best results for all parties involved? By investigating executives' opinions on these types of questions researchers may begin to understand the impact and importance of these results to an agency.

Clearly, history has shown there is value in fingerprint and DNA evidence in reference to criminal justice matters. This evidence is important to gather and analyze. What has not been shown are the best ways of achieving the optimal results.

\section{Problem Statement}

The criminal justice system has come to rely heavily on the results of the forensic examination of evidence collected at crime scenes, especially fingerprint and DNA evidence. The proper collection and submission of this evidence is crucial to the prosecution of a case and the identification of an individual. This evidence collection has been done by a variety of individuals, from the first responding law enforcement personnel to the highly trained civilian lab/crime scene personnel. There has never been a set standard for crime scene processing or evidence collection. Agencies set up their units according to their needs and abilities. Depending on the methodology of the collection and by whom this is being conducted, the results may differ substantially. An analysis of the results from evidence collected by first responding law enforcement personnel versus that collected by trained professionals should be done to determine which is the best practice. This data has never truly been analyzed or compared. Many agencies unknowingly collect this data however they do not store this information in an easily accessible manner. By conducting a comparison of these results, agencies, state attorney's offices, and the criminal justice system as a whole will be able to implement standard operating procedures that will lead to the best results and ultimately successful prosecutions. 


\section{Purpose and Objective of the Study}

History has shown that fingerprint and DNA evidence are crucial elements found at a crime scene. Throughout the centuries this evidence has been identified, collected, preserved, and processed in numerous ways. With the daily changing techniques in crime scene processing and the technologies available, continuous training, education, and understanding of how to properly collect this vital evidence is crucial. If this evidence is improperly handled at any point in time, criminal cases may be lost. The purpose of this study is to compare the methods being utilized by different agencies to properly identify, collect, and preserve fingerprint and DNA evidence from crime scenes and determine what Police Chiefs/Sheriffs believe the best practice is to obtain the optimal results. The comparisons will involve evidence collection that is done by first responding law enforcement personnel, law enforcement personnel that are specially trained and in dedicated crime scene units, and civilian crime scene investigators. Data collected from Police Chiefs/Sheriffs may assist in finding the best practices that will lead to identifications of individuals at crime scenes. The identifications may be victims or suspects, both of which are important in criminal investigations. The focus is that identification is in fact made based on the way the evidence was collected. Another factor that will be evaluated is the cost involved to employ these valuable personnel. Once the best practice has been determined for which type of personnel should be utilized a cost comparison will be done to analyze the results an agency will receive and what these results may cost them.

\section{Rationale of the Study}

Crime scene processing is an expense for any law enforcement agency, however this expense must be made in order to close cases and identify individuals at crime scenes. With developing technologies, the cost of processing fingerprint and DNA evidence incrementally increases year by year. This means that Police Chiefs/Sheriffs try to find the least expensive way to handle their crime scene processing even though these methods may not give the best results. Therefore agencies must choose which is more important, cost savings or identifications of persons on crime scenes and ultimately prosecutions. This study is exploratory research into the types of personnel being utilized by agencies in their forensic processing. This study is going to evaluate the types of personnel being utilized by agencies to collect fingerprints and DNA from crime scenes. The study will also discuss the costs involved with the three levels of crime scene processors being utilized: first responding law enforcement, specialized law enforcement, and civilians. Comparisons of Police Chiefs/Sheriffs' opinions on the results from the evidence collected by these groups will be done to evaluate which group is believed to be able to identify the most people from a crime scene or if there is a perception of there being no difference in the results. By evaluating the cost related with employing these members and their evidentiary results, agencies may have a better understanding of the pros and cons of each and determine the best way to proceed in future years.

\section{Limitations of the Study}

Data will be collected from internet survey input from multiple agencies. Depending on how an agency processes crime scenes and the availability of laboratory results, data available may be limited. Opinions of Police Chiefs/Sheriffs were collected and compared. The actual numbers collected from the results of the agencies received from the differing groups of evidence collectors should be analyzed to confirm or deny the opinions established in this study. The data collected was from law enforcement agencies in the state of Florida; this limits the study's findings to this state. More research would need to be conducted in other states and nations.

The surveys were sent out through email. The email addresses were obtained from the Florida Department of Law Enforcement. The surveys were sent to four hundred eight (408) total agencies in Florida. A total of thirty-four (34) agencies provided responses to the survey questions.

\section{Research Hypotheses}

1. Police Chiefs/Sheriffs believe that evidence collected by first responding law enforcement personnel show no significant difference in the number of identifications than evidence collected by trained civilian or sworn crime scene investigators.

2. Police Chiefs/Sheriffs believe that evidence collected by first responding law enforcement personnel will show no significant difference in the number of prosecutions than evidence collected by trained civilian or sworn crime scene investigators.

3. There is no significant difference in cost for an agency to employ a highly trained civilian crime scene investigator compared to employing a sworn member.

4. Police Chiefs/Sheriffs believe that sworn crime scene investigators who perform crime scene processing solely will show no significant difference in identifications compared to highly trained civilian crime scene investigators.

\section{Methodology}

\section{Setting}

The data for this study was collected from online surveys. 


\section{Description of the Subjects}

This study involves data collected from thirty-four law enforcement agencies. The data focused on forensic evidence being collected by different subjects at these agencies. The subjects that collected the evidence were of three different levels, sworn first responding law enforcement, sworn crime scene investigators, and civilian crime scene investigators. For this study there is an attempt to separate first responding law enforcement officers whose primary function is answering calls for service from a communications center and law enforcement officers whose primary function is processing crime scenes. Many agencies use their personnel in different ways. Some law enforcement officers are assigned to a Crime Scene Unit where their primary job is to process crime scenes. Typically these officers receive more specific training and have more experience in processing. Other agencies utilize officers whose primary job is answering calls for service as "part time" crime scene investigators. These officers usually receive minimal training and are required to perform other primary job duties before crime scene related duties. This study attempts to compare the perceived results of forensic evidence collected by these two entities as well as full time civilian Crime Scene Investigators. The basis of this study was the forensic results received from the subjects. The subjects were not studied in any way.

\section{Description of Research Instruments}

Surveys have long been an important facet of research methods. Survey research began around the 1930s with an article written by Neymann that presented sampling and measurable errors [3]. Since this time survey research has grown and developed in social studies. Original surveys were mainly conducted in person, by mail, or over the telephone [4]. Innovations in technology brought about internet surveys. Internet surveys offer great advantages to researchers. Internet surveys are much more cost effective for the researcher, saving them money in postage and training [4]. Internet surveys also allow for more visually appealing surveys, more interactive options, and quicker easily retrieved and organized responses [4]. Although internet surveys have great advantages there are always disadvantages to every methodology. One of the biggest disadvantages or challenges that researchers face with internet surveys is coverage capabilities of the respondents [4]. In this research the respondents were all law enforcement agencies whose agencies are based on internet connectivity, thus eliminating the concern of coverage challenges.

Dr. Don Dillman has authored numerous studies about the methodologies of survey research. The fundamentals of survey research are found in the Total Design Method (TDM) that was created by Dillman in 1978 [5]. The original TDM was written for surveys that were conducted in person or over the telephone. As technologies have developed that change the way surveys are distributed Dillman updated the design method to include internet distribution of surveys [6]. The updated version of the TDM held the same principles as the original. Regardless of which method the researcher uses for distribution (phone, in person, or internet) the basic fundamentals to receive higher results and feedback remain the same. Dillman suggests sending a follow up post card or letter one week after the initial survey was sent out, a second copy of the survey four weeks after the initial, and a third copy seven weeks after [5].

The research data for this thesis was collected utilizing the TDM theories. Electronic surveys were sent out and a follow up letter was sent a week later. Due to the complete anonymity of the participants follow up letters and secondary surveys were sent to all of the original participants. Statements were included in the follow- ups that reiterated the anonymity of the participants and thanked them for their responses if they had already been given.

The information for this study was gathered by sending electronic surveys to the heads of numerous Florida law enforcement agencies. The contact information for these executives was obtained from the public information listed on the Florida Department of Law Enforcement website. The data was collected by utilizing a survey that was created in Google Forms: (https://docs.google. com/forms/d/14pnv5OKdTtCZVxlfZmSBbkyp3ltG3FriTb86tbtyM6A/edit). The data was submitted anonymously through this forum. Once the participant answered the survey questions and submitted the data, the information was automatically date stamped and entered into a spreadsheet with no identifying features connected (Appendices C-F).

The statistical analytical tools for testing the hypotheses in this study were the one-way analysis of variance (ANOVA) test and the two-sample t-test. The goal of the research in this study is to compare the results from forensic evidence collected at three levels of crime scene response personnel to determine which level Police Chiefs/Sheriffs perceive will give an agency the best results and also to evaluate the cost involved in employing these members. The opinion questions were ranked 1-5 for each relevant question. The ANOVA test is utilized when comparing mean results from at least three independent test groups, such as those in this study. The ANOVA test evaluates the means of three or more independent groups to determine if they are equal to each other, in other words, the null hypothesis, $\mathrm{H}_{0}: \mu_{1}=\mu_{2}=\mu_{3} \ldots \ldots \mu_{k}$. In the null hypothesis stated, $\mu=$ the group mean and $\mathrm{k}=$ the number of groups [7]. The ANOVA test however will only indicate if there is a significant difference between the multiple groups. This test will not specify between which two groups the difference lies. Therefore a secondary instrument was utilized as a post-hoc test, the twosample t-test. Whereas the ANOVA test compares the means of three or more groups the $t$-test compares the means of only two groups and will clearly indicate which group has a statistically significant difference, if there is one. The $t$-test null hypothesis is $\mathrm{H}_{0}$ : $\mu_{1}=\mu_{2}$ where $\mu_{1}$ is the mean of the first group and $\mu_{2}$ is the mean of the second group [8]. The instrument tests used for this study were obtained from: http://www.vassarstats.net/ and http://www.graphpad.com/quickcalcs/ttest2. 


\section{Procedures}

Electronic surveys were sent out to four hundred eight agencies in Florida asking specific questions in reference to the hypotheses of this study. The survey questions and cover letter are included in Appendix A. The surveys were sent directly to the heads of the law enforcement agencies. One week after the original surveys were sent out a follow up letter was sent. Due to the complete anonymity of the respondents the follow up letter was sent to all of the original participants. The follow up letter may be found in Appendix B. Prior to distribution, a pre-test of the survey was done.

\section{Pre-test}

The survey was pre-tested multiple times prior to disbursement by veteran Crime Scene Investigators.

\section{Distribution and Result Collection}

After the completion of the pre-test, the surveys were emailed to the Police Chiefs and Sheriffs of Florida agencies. The survey was created utilizing Google Forms: (https:/docs.google.com/forms/d/14pnv5OKdTtCZVxlfZmSBbkyp3ltG3FriTb86tbtyM6A/edit). This forum allowed for complete anonymity for the reporting agency. The respondents answered the survey electronically at their leisure. The results were automatically date stamped, organized by question and category, and compiled into a spreadsheet once submitted by the respondent.

Based on the hypotheses of this study, a separate spreadsheet was made based on the information from the automatic spreadsheet created by the survey instrument. This new spreadsheet broke down the results into categories by personnel collecting the evidence, number of identifications (if available), number of prosecutions (if available), and the salary, retirement, overtime, and education of the personnel (Appendices C-F). For questions that were "not applicable" or left blank, a ranking of 0 was assigned.

Overtime in law enforcement is typically given at a rate of straight time (an employee's hourly wage) or time and a half (an employee's hourly wage multiplied by 1.5). In order to utilize the statistical tests for comparison, any answers given as "straight time" were ranked as a number 1 and answers indicating "time and a half" were ranked as number 2.

Salaries were provided in ranges. The ranges were ranked to utilize the information in the statistical tests (Appendix E).

Some law enforcement personnel are classified as "special" risk for the purposes of retirement. This is often considered a benefit since they are able to obtain more money for retirement. Answers to the retirement category questions were "yes/no" and were ranked. "Yes" was ranked as number 1 and "no" was ranked as number 2.

The average education was determined based on each category for informational purposes. No statistical comparison of this information was done.

Respondents answered the opinion questions with a number 1 - 5. Number 1 was least likely and number 5 was most likely. Two of the opinion questions were "yes/no" questions. For the "yes/no" questions; "yes" was ranked as a 1 and "no" was ranked as a 2. The numerical values obtained from the respondents for the opinion questions facilitated the statistical analyses.

Hypothesis 1: Police Chiefs/Sheriffs believe that evidence collected by first responding law enforcement personnel shows no significant difference in the number of identifications than evidence collected by trained civilian or sworn crime scene investigators.

The raw data that was provided by the differing agencies was organized into a spreadsheet (Appendix C). Utilizing the ANOVA test, the number answers from the opinions of the executives in relation to the results of identifications from fingerprints and DNA for the categories of first responding law enforcement, civilian CSIs, and sworn CSIs were compared and analyzed. The ANOVA test was conducted through http://www.vassarstats.net/. If a statistically significant difference was observed the $t$-test was implemented to determine between which groups the difference lies. The $t$-test was conducted through http://www.graphpad.com/ quickcalcs/ttest1/. Based on the significance indicated this hypothesis will be accepted or rejected.

Hypothesis 2: Police Chiefs/Sheriffs believe that evidence collected by first responding law enforcement personnel will show no significant difference in the number of prosecutions than evidence collected by trained civilian or sworn crime scene investigators.

The raw data that was provided by the differing agencies was organized into a spreadsheet (Appendix D). Respondents were asked about civilian and sworn CSIs in the same question. This provided one test group of "CSIs" which included both sworn and civilian. Respondents were asked about first responders in another question. Utilizing the $t$-test, the numerical answers from the opinions of the executives in relation to the results of prosecutions based on evidence collected by the categories of first responding law enforcement, civilian CSIs, and sworn CSIs were compared and analyzed. The $t$-test was conducted through http://www. graphpad.com/quickcalcs/ttest1/. Based on the significance indicated this hypothesis will be accepted or rejected.

Hypothesis 3: There is no significant difference in cost for an agency to employ a highly trained civilian crime scene investigator compared to employing a sworn member. 
The raw data that was provided by the differing agencies was organized into a spreadsheet (Appendix E). Respondents' only provided answers if they had personnel in the appropriate categories. Those questions that were not answered were eliminated from the statistics. Utilizing the $t$-test, the salaries, retirement, and overtime rate of pay of the categories of civilian CSIs and sworn CSIs were totaled, compared, and analyzed. The $t$-test was conducted through http://www.graphpad.com/quickcalcs/ttest2/. Based on the significance indicated this hypothesis will be accepted or rejected.

Hypothesis 4: Police Chiefs/Sheriffs believe that sworn crime scene investigators who perform crime scene processing solely will show no significant difference in identifications compared to highly trained civilian crime scene investigators.

The raw data that was provided by the differing agencies was organized into a spreadsheet (Appendix F). Utilizing the $t$-test, the number answers of the opinions of the executives in relation to the identifications from fingerprints and DNA for the categories of civilian CSIs and sworn CSIs were compared and analyzed. The t-test was conducted through http://www.graphpad.com/ quickcalcs/ttest2/. Based on the significance indicated this hypothesis will be accepted or rejected.

\section{Results}

\section{Pre-test Results}

The survey was pre-tested prior to disbursement by veteran Crime Scene Investigators. The pre-test respondents indicated they had been working in the crime scene related field for an average of 8.6 years. The majority of the pre-test respondents were members of their Crime Scene Units. The survey was adapted based on input from these members. Several agencies reported that finding the raw data requested in questions 23-34 would be very time consuming and nearly impossible. This led to the addition of opinion based questions numbers 35-44 in order to obtain data in reference to the topic. Some respondents were able to provide the information for questions 23-34 therefore those questions remained in the final survey with hopes that other agencies may be able to obtain the data. The survey was sent out again with the additional opinion questions. The feedback was much more positive. Respondents stated the survey was much easier to answer with the opinion based questions. They also reported that the survey only took them approximately 12 minutes to complete and was easy to follow and understand.

The survey consisted of a total of forty-eight questions. The questions varied in style from multiple choices, yes/no, and fill in the blank. Questions 1-7 inquired about an agency's current forensic response. These questions were utilized to gain an understanding of how an agency operates their Crime Scene Units. None of this information was used for statistical analysis. Questions 8-22 referenced the pay and education of the agency's first responders and Crime Scene Unit members. Educational questions were not used for statistics in this research; however an interesting trend was noticed. Based solely on the answers, civilian CSIs appeared to have a much higher educational requirement by agencies and more years of experience versus their sworn counterparts or first responders. This would be an interesting future study. In this range of questions, specifically questions 11-19 were utilized for statistical testing in this study to establish salary, overtime, and retirement.

The respondents for this study indicated an average of 21 years in law enforcement. The positions held by respondents ranged from Crime Scene Supervisors to Police Chiefs. All respondents reported experience in the forensic field.

The study outcomes reflected the pre-test results the majority of agencies were unable to provide raw data for questions 23-34. Most agencies answered these questions N/A (not applicable) or left them blank. Due to this limitation these questions were eliminated from the statistical testing. The opinion answers in questions 35-44 were utilized to capture this information. Agencies that did not have a civilian CSI or a sworn CSI left some questions blank or answered them N/A. For the comparisons of these groups, questions left blank or N/A were eliminated from the statistical testing. This is a clear indication of an area of research that needs to be expanded on in the future.

Hypothesis 1: Police Chiefs/Sheriffs believe that evidence collected by first responding law enforcement personnel show no significant difference in the number of identifications than evidence collected by trained civilian or sworn crime scene investigators.

The raw data provided by respondents may be found in Appendix C. A one-way ANOVA test was conducted to compare the Police Chiefs/Sheriffs beliefs of receiving identifications on fingerprint and DNA evidence by first responders and CSIs both sworn and civilian.

There was a statistically significant difference between first responders and CSIs for fingerprint and DNA identifications (Table 1).

\begin{tabular}{|c|c|c|c|c|c|c|c|c|c|c|}
\hline & \multicolumn{4}{|c|}{ Fingerprint identifications } & \multicolumn{4}{c|}{ DNA identifications } \\
\hline & df & MS & SS & F & Sig. & df & MS & SS & F & Sig. \\
\hline First Responders & 2 & 7.95 & 15.90 & 3.14 & .048 & 2 & 11.60 & 23.20 & 4.37 & .015 \\
\hline CSIs (civ. \& sworn) & 99 & 2.53 & 250.62 & & & 99 & 2.65 & 262.65 & & \\
\hline
\end{tabular}

Note: $\mathrm{p}<0.05$ is indicative of a significant difference

$\mathrm{N}=34, \mathrm{Q}=408, \mathrm{df}=$ Degree of Freedom, $\mathrm{SS}=$ Sum of squares, $\mathrm{MS}=$ Mean Square, Sig. = p value

Table 1: First Responders vs. CSIs (civilian and sworn) for fingerprint and DNA identifications 
Based on the ANOVA test results there is a statistically significant difference in both fingerprint and DNA identifications between first responders and CSIs (both civilian and sworn).

In order to determine which groups the statistical difference lies the $t$-test was implemented for each of the groups.

There was a statistically significant difference in the identifications on fingerprint and DNA evidence for first responders and civilian CSIs and sworn CSIs and civilian CSIs (Table 2).

There was not a statistically significant difference in the identifications on fingerprint and DNA evidence between first responders and sworn CSIs (Table 2).

\begin{tabular}{|c|c|c|c|c|c|c|c|c|c|c|c|c|}
\hline \multicolumn{7}{|c|}{ Fingerprint identifications } & \multicolumn{6}{|c|}{ DNA identifications } \\
\hline & Mean & SD & $\begin{array}{l}\text { Standard } \\
\text { Error Mean }\end{array}$ & $\mathbf{t}$ & df & $\mathbf{P}$ & Mean & SD & $\begin{array}{l}\text { Standard } \\
\text { Error Mean }\end{array}$ & $\mathbf{t}$ & df & $\mathbf{P}$ \\
\hline First Responders & 2.41 & 1.23 & 0.21 & 2.11 & 66 & 0.04 & 2.38 & 1.33 & 0.23 & 2.50 & 66 & 0.01 \\
\hline Civilian CSIs & 3.15 & 1.62 & 0.28 & & & & 3.29 & 1.66 & 0.28 & & & \\
\hline First Responders & 2.41 & 1.23 & 0.21 & 0.46 & 66 & 0.65 & 2.38 & 1.33 & 0.23 & 0.45 & 66 & 0.65 \\
\hline Sworn CSIs & 2.24 & 1.86 & 0.32 & & & & 2.21 & 1.86 & 0.32 & & & \\
\hline Sworn CSIs & 2.24 & 1.86 & 0.32 & 2.16 & 66 & 0.04 & 2.21 & 1.86 & 0.32 & 2.55 & 66 & 0.013 \\
\hline Civilian CSIs & 3.15 & 1.62 & 0.28 & & & & 3.29 & 1.66 & 0.26 & & & \\
\hline
\end{tabular}

Note: $\mathrm{p}<0.05$ is indicative of a significant difference.

$\mathrm{N}=34, \mathrm{Q}=408, \mathrm{SD}=$ Standard Deviation, $\mathrm{df}=$ Degree of Freedom, $\mathrm{P}$ is a two tailed test

Table 2: Fingerprint and DNA identifications for first responders vs. Civilian CSIs, first responders vs. Sworn CSIs, and Civilian vs. Sworn CSIs

These results suggest that Police Chiefs/Sheriffs believe they will achieve a higher success rate of identifications for both fingerprint and DNA evidence if this evidence is collected by a trained civilian CSI versus a first responder. Interestingly enough, respondents do not believe they will achieve higher success rates in identifications for fingerprints or DNA utilizing sworn CSIs or first responders. This indicates that the lead decision makers of law enforcement agencies, the Police Chiefs/Sheriffs, believe that civilian CSIs will give them the best results for both fingerprint and DNA evidence. This leads to the rejection of Hypothesis 1.

Hypothesis 2: Police Chiefs/Sheriffs believe that evidence collected by first responding law enforcement personnel will show no significant difference in the number of prosecutions than evidence collected by trained civilian or sworn crime scene investigators.

The raw data provided by respondents may be found in Appendix D. A t-test was conducted to compare the Police Chiefs/Sheriffs beliefs of receiving a prosecution based on evidence collected by first responders and CSIs, both civilian and sworn (Table 3). There was a statistically significant difference in the belief of achieving a successful prosecution based on evidence collected by first responders and CSIs.

\begin{tabular}{|c|c|c|c|c|c|c|}
\hline \multicolumn{7}{|c|}{ Prosecutions } \\
\hline & Mean & SD & $\begin{array}{c}\text { Standard } \\
\text { Error Mean }\end{array}$ & t & df & P \\
\hline First Responders & 2.91 & 1.11 & 0.19 & 2.73 & 66 & 0.01 \\
\hline CSIs (sworn \& civilian) & 3.68 & 1.20 & 0.21 & & & \\
\hline
\end{tabular}

Note: $\mathrm{p}<0.05$ is indicative of a significant difference.

$\mathrm{N}=34, \mathrm{Q}=408, \mathrm{SD}=$ Standard Deviation, $\mathrm{df}=$ Degree of Freedom, $\mathrm{P}$ is a two tailed test

Table 3: Prosecutions for first responders vs. CSIs

The results suggest that Police Chiefs/Sheriffs believe they are far more likely to obtain a prosecution if evidence is collected by a CSI, sworn or civilian rather than a first responder. This leads to the rejection of Hypothesis 2.

Hypothesis 3: There is no significant difference in cost for an agency to employ a highly trained civilian crime scene investigator compared to employing a sworn member.

The salary, retirement, and overtime for civilian crime scene personnel and sworn crime scene personnel were ranked and then totaled.

The raw data provided by respondents may be found in Appendix E. A t-test was conducted to compare the totals of the salary, retirement, and overtime for sworn CSIs and civilian CSIs (Table 4). There was no statistically significant difference in the salary, retirement, and overtime for sworn CSIs and civilian CSIs.

The results suggest that when an agency looks at the total salary, overtime, and retirement for a CSI they will not spend more money if they hire a civilian or a sworn member. These results lead to the acceptance of Hypothesis 3. 


\begin{tabular}{|c|c|c|c|c|c|c|c|}
\hline \multicolumn{7}{|c|}{ Salaries, retirement, and Overtime } \\
\hline & N & Mean & SD & $\begin{array}{c}\text { Standard } \\
\text { Error Mean }\end{array}$ & t & df & P \\
\hline Sworn CSIs & 10 & 4.90 & 2.64 & 0.84 & 1.89 & 30 & 0.07 \\
\hline Civilian CSIs & 22 & 6.36 & 1.71 & 0.36 & & & \\
\hline
\end{tabular}

Note: $\mathrm{p}<0.05$ is indicative of a significant difference.

$\mathrm{Q}=408, \mathrm{SD}=$ Standard Deviation, $\mathrm{df}=$ Degree of Freedom, $\mathrm{P}$ is a two tailed test

Table 4: Salary, retirement, and overtime totals for civilian CSIs vs. Sworn CSIs

Hypothesis 4: Police Chiefs/Sheriffs believe that sworn crime scene investigators who perform crime scene processing solely will show no significant difference in identifications compared to highly trained civilian crime scene investigators.

The raw data provided by respondents may be found in Appendix F. A t-test was conducted to compare the Police Chiefs/Sheriffs beliefs of receiving identifications on DNA and fingerprint evidence by civilian CSIs and sworn CSIs (Table 5). There was a statistically significant difference in the identifications on DNA evidence for sworn CSIs and civilian CSIs.

\begin{tabular}{|c|c|c|c|c|c|c|c|c|c|c|c|c|}
\hline & \multicolumn{5}{|c|}{ Fingerprint identifications } & \multicolumn{5}{c|}{ DNA identifications } \\
\hline & Mean & SD & $\begin{array}{c}\text { Standard } \\
\text { Error Mean }\end{array}$ & $\mathbf{t}$ & $\mathbf{d f}$ & $\mathbf{P}$ & Mean & SD & $\begin{array}{c}\text { Standard } \\
\text { Error Mean }\end{array}$ & $\mathbf{t}$ & $\mathbf{d f}$ & $\mathbf{P}$ \\
\hline Sworn CSIs & 2.24 & 1.86 & 0.32 & 2.16 & 66 & 0.03 & 2.21 & 1.86 & 0.32 & 2.55 & 66 & 0.01 \\
\hline Civilian CSIs & 3.15 & 1.62 & 0.28 & & & & 3.29 & 1.66 & 0.26 & & & \\
\hline
\end{tabular}

Note: $\mathrm{p}<0.05$ is indicative of a significant difference.

$\mathrm{N}=34, \mathrm{Q}=408, \mathrm{SD}=$ Standard Deviation, $\mathrm{df}=$ Degree of Freedom, $\mathrm{P}$ is a two tailed test

Table 5: DNA and fingerprint identifications for sworn vs. Civilian CSIs

These results suggest that Police Chiefs/Sheriffs believe they will achieve a higher success rate of identifications for both fingerprint and DNA evidence if this evidence is collected by a trained civilian CSI versus a sworn CSI. This leads to the rejection of Hypothesis 4 .

\section{Discussion, Conclusion, and Recommendations}

This study looked at Police Chiefs/Sheriffs beliefs concerning best practices for forensic evidence collection. These leaders are typically the decision makers in the way their agencies' Crime Scene Units are created and the manpower that is utilized. This study examined one of the most important factors in forensic evidence collection, the personnel doing the physical collection. This is something that has not been extensively researched and is believed to have an impact on the forensic results received by agencies.

\section{Hypothesis 1}

Police Chiefs/Sheriffs believe that evidence collected by first responding law enforcement personnel shows no significant difference in the number of identifications than evidence collected by trained civilian or sworn crime scene investigators.

This hypothesis was rejected during this study. The respondents in this study indicated that they do in fact believe that they will receive different results dependent on who collects their evidence. The Police Chiefs/Sheriffs indicated that they believe Civilian CSIs will give them the best results. This is an interesting result since many agencies have started to split the forensic workload between their Crime Scene Units and their road patrol. If Police Chiefs/Sheriffs in fact believe they will receive less than adequate results from their road patrol perhaps the trend for the future should be to employ more civilian CSIs and eliminate the forensic responsibility from first responders. According to the results of this study this would give agencies the best forensic results, more prosecutions, and not cost an agency any more money.

\section{Hypothesis 2}

Police Chiefs/Sheriffs believe that evidence collected by first responding law enforcement personnel will show no significant difference in the number of prosecutions than evidence collected by trained civilian or sworn crime scene investigators.

This study led to the rejection of this hypothesis. The respondents in this research indicated that they believe a CSI, whether sworn or civilian, will give them more prosecutions than a first responder. These results coincide with the findings in hypothesis 1 . This again leads to questions in regards to agencies splitting their forensic responsibility between their Crime Scene Units and their first responders. If the agency leaders believe that they will achieve better results and receive more prosecutions utilizing CSIs perhaps the trend should be moving away from splitting the forensic responsibility with the first responders.

\section{Hypothesis 3}

There is no significant difference in cost for an agency to employ a highly trained civilian crime scene investigator compared to employing a sworn member. 
This research led to the acceptance of this hypothesis. Comparing the salary, retirement, and overtime categories for sworn and civilian personnel indicated that an agency spends no more money for one over the other. The majority of agencies pay their civilian personnel in the same manner as their sworn personnel. The majority of agencies gives both categories of personnel time and half for overtime and considers them high risk for retirement. Interestingly enough the results show that civilian employees are typically paid at a lesser rate than sworn employees, making them the more economical choice. Building upon the first two hypotheses a beneficial plan for forensic processing is developing. Agency leaders believe they will achieve the best results with civilian CSIs, they also believe they will receive more prosecutions with this group, and this hypothesis shows that there are no additional costs for an agency to hire these personnel. The clear implication from the research is that agencies should seriously consider incorporating more civilian CSIs into their forensic processing plans.

\section{Hypothesis 4}

Police Chiefs/Sheriffs believe that sworn crime scene investigators who perform crime scene processing solely will show no significant difference in identifications compared to highly trained civilian crime scene investigators.

The research indicated that Police Chiefs/Sheriffs believe that civilian CSIs will give them better results than sworn CSIs. Not only do the leaders of agencies believe that civilian CSIs will give them better results than first responders but they also believe they will surpass their sworn counterparts.

\section{Conclusions}

Respondents stated in this study that they do believe there is a difference in the results they would receive dependent on who does the evidence collection. As anticipated, respondents believe that trained Crime Scene Investigators will give them the best results. However, a very curious phenomenon occurred during this study. When the respondents were asked directly if sworn CSIs or civilian CSIs would yield better results for their agency (Question 41) the majority (85\%) responded they did not believe there would be a difference. However, when asked to rank their belief numerically as to which group would provide the best results (Hypothesis 4) they responded that they believe civilian CSIs would give better results. This leads to an interesting concept for the progression of forensic evidence collection. If executives believe that civilian CSIs will obtain better results perhaps this is the way of the future in this field. This trend has begun to show throughout the country. Many agencies have started to switch their Crime Scene Units into fully civilian units. Based on the research in this study, this trend makes sense for agencies. Based on the hypotheses in this study agencies do not spend any more money on civilian CSIs versus sworn CSIs (Hypothesis 3 ). If this in fact is true and they believe they will achieve better forensic results and prosecutions (Hypothesis 2) the logical choice for agencies would be to civilianize their units.

\section{Recommendations}

This study is the first of many that should follow. There is a clear gap in the literature as well as in the forensic field when it comes to who physically does forensic evidence collection. The literature does indicate that there is an obvious importance and value to forensic evidence. Evidence such as fingerprints and DNA are crucial to criminal cases. The law enforcement community works very diligently to find, arrest, and prosecute criminals. The forensic aspect of this intricate process is very evident throughout history and continues today. Agencies should consider how this important evidence is being collected. With the advances in technology forensic evidence collection is constantly changing. These changes require an understanding of the evolution in this technology. The best personnel to understand this and dedicate their time to researching and understanding the changes would be CSIs. This research indicates the Police Chiefs and Sheriffs of law enforcement agencies believe civilian CSIs are the best evidence collectors and they believe that first responders will produce less prosecutions and identifications. These results conflict with the trends being seen in agencies today. Many agencies are beginning to make their Crime Scene Units more civilian however a progression towards first responders collecting evidence is also taking place. This is a clear contradiction to the leaders' personal beliefs as to "best practice".

While gathering data for this research many questions were unable to be answered by agencies since this data is not collected by the agency. This is indicative that agencies have not thought about whom the evidence collectors are in any great detail nor do they collect the data needed to confirm who the best evidence collectors are. Agencies should consider collecting data in reference to their forensic results. Studies should be compiled that research the actual numbers of identifications and prosecutions dependent on the collector to ensure what best practices truly are.

Studies should also be done to investigate the actual costs to employ differing personnel. This study indicated there is no real cost difference to employ a civilian or a sworn member. This information was based on salary, overtime, and retirement. Further studies looking into the cost of training, equipment, schooling, etc. should be done to completely understand the costs involved for an agency to hire these personnel.

By continuing to gather data and understand the impact of the personnel collecting forensic evidence, agencies will be able to better equip themselves for better forensic results, more prosecutions and ultimately more peace in their communities. 


\section{Acknowledgements}

I would like to take the time to thank several persons who assisted me greatly in this achievement. I would like to begin by thanking my entire panel committee, especially Dr. Saviak. Without your endless support and guidance, this project would have been only a dream. I am very grateful for your assistance in this process. I would also like to thank Ephryn Thompson whose computer knowledge and assistance with the forms and surveys helped me begin and complete this research. Lastly, I would like to thank my family and friends who have supported and stood by me during this very difficult time. Your understanding and continued belief in me pushed me to completion. Thank you.

\section{References}

1. Pray LA (2014) Discovery of DNA Structure and Function: Watson and Crick. Nature Education.

2. Noble A, Prottas JM (2007) Use of Forensic DNA Evidence in Prosecutor's Offices. J Law Med Ethics 310.

3. Groves RM (2011) Three Eras of Survey Research. Pubib Opinion Quarterly 75: 861-71.

4. Nathan G (2008) Internet Surveys. Encyclopedia of Survey Research Methods. SAGE Publications Inc 357-60.

5. Dillman A. (1991) The Design and Administration of Mail Surveys. Annu Rev Sociol 17: 225-49.

6. Dillman A (2014) The Tailored Design Method. Washington State University.

7. Research L (2013) One-way ANOVA.

8. Sematech N (1989) Two-Sample t-test for Equal Means.

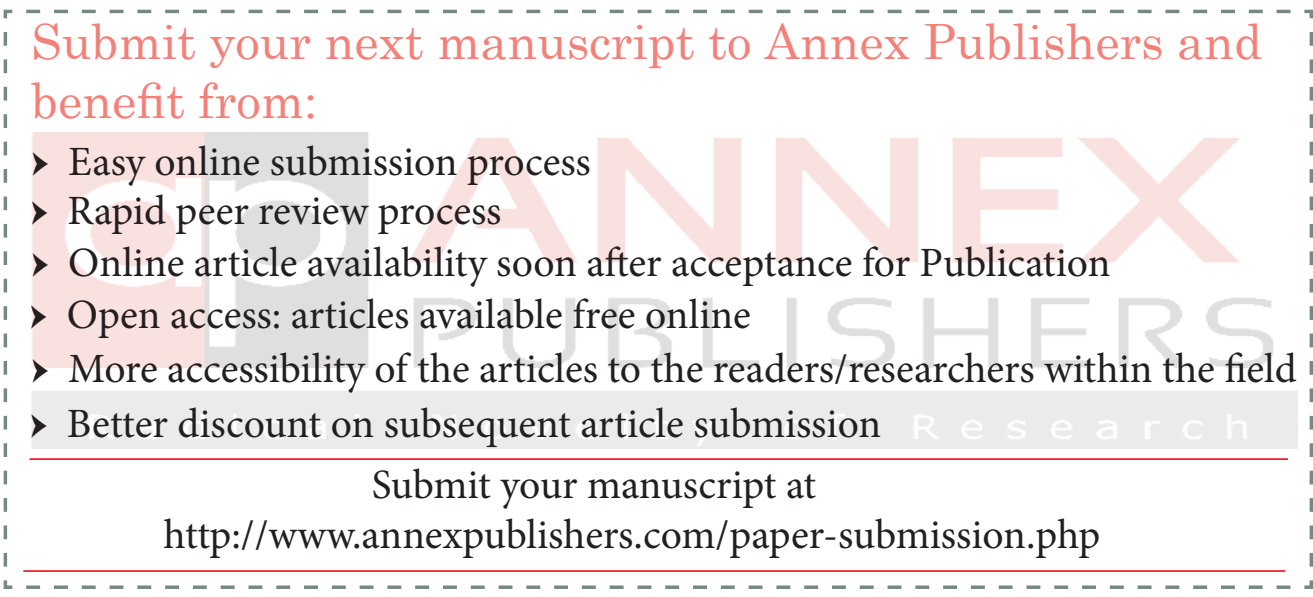

